Mitchell, P. \& Moyle, J. (1954). J. gen. Microbiol. 10, 533-540.

\title{
The Gram Reaction and Cell Composition : Nucleic Acids and other Phosphate fractions
}

\author{
By P. MITCHELL AND JENNIFER MOYLE \\ Department of Biochemistry, University of Cambridge
}

SUMMARY: The content of ribonucleic acid (RNA), excess organic phosphate (XSP) in the RNA fraction, deoxyribonucleic acid (DNA), acid-soluble inorganic phosphate (AI) and organic phosphate (AO), and the lipid phosphate (LP) and lipid weight $(\mathrm{L})$ have been determined in some ten Gram-positive and ten Gram-negative organisms, grown in the same media and harvested at the same phase of growth. A statistical analysis of the results shows that the RNA and DNA contents of the Gram-positive and Gram-negative groups do not differ significantly; the percentage of lipid phosphorus is only half as great in the Gram-positive as in the Gram-negative group; and XSP is present in all the Gram-positive organisms, but absent from all the Gram-negative ones. We suggest that a lipid-polyglycerophosphate-protein component may be a common structural feature of the cell envelopes of all Grampositive organisms. The mechanism of the Gram reaction is considered in the light of our observations.

The Gram staining reaction has generally been considered to be caused by a special cell component, and opinion has been more or less equally divided as to whether this component is a substance which adsorbs the dye-iodine complex specifically or whether it is a barrier which prevents the outward diffusion of this complex. In either case, it would be expected that the capacity for retaining the dye-iodine complex would be reflected in the composition of the cells. Since Gram introduced his method of staining in 1884, it has become clear that the individual members of the Gram-positive and Gramnegative groups of organisms have in common not only their respective staining characteristics but also many general physiological characteristics. The study of Gram staining is therefore all the more interesting, since an explanation of the mechanism must involve a description of physiologically important differences of composition and structure between the two groups.

Very few comparative studies have been made on the chemical composition of Gram-positive and Gram-negative bacteria. For a small number of organisms, data are however available on the composition of the protein, the content of ribonucleic acid (RNA), the content of a phosphate ester (XSP) which occurs in the RNA fraction, and the magnesium content. The observations of Camien, Salle \& Dunn (1945), Stokes \& Gunness (1946) and Freeland \& Gale (1947) on the amino acid composition of the whole protein of four Gram-negative and seven Gram-positive organisms showed no systematic differences except in the arginine content. In the Gram-positive organisms studied, the arginine represents $c .450 \mu \mathrm{mole} / \mathrm{g}$. cell dry weight, whereas in the Gram-negative organisms it represents $c .900 \mu \mathrm{mole} / \mathrm{g}$. A corresponding difference occurs in the composition of the protein of the cell walls of five 
Gram-positive and two Gram-negative organisms. The cell walls of Staphylococcus aureus (Micrococcus pyogenes) (Mitchell \& Moyle, 1951 c) and of Streptococcus pyogenes, Strep. faecalis, Micrococcus lysodeikticus and Sarcina lutea (Salton, 1953) were found to contain practically no arginine, nor did they contain methionine, cysteine, phenylalanine or tyrosine. On the other hand, arginine and the sulphur-containing and aromatic amino acids were found in the cell walls of Escherichia coli and Salmonella pullorum (Salton, 1953). Stacey (1947) reported that whereas in several Gram-negative bacteria the ratio of ribonucleic acid to deoxyribonucleic acid (RNA/DNA) is only $1 \cdot 3 / 1$, in Clostridium welchii and streptococci it is greater than $8 / 1$-implying that Gram-positive bacteria in general contain much more RNA than Gramnegative bacteria. Boivin (1948) and Mitchell \& Moyle (1950) were unable to find the differences claimed by Stacey. But Mitchell \& Moyle (1950, 1951 $a$ ) observed that the RNA fraction (Schmidt \& Thannhauser, 1945) of several Gram-positive bacteria contained a large excess of organic phosphate attributable to a new phosphoric ester (XSP) which was not present in Gram-negative organisms. In Staph. aureus, this ester was later shown to be a polyglycerophospho-compound which is a major component of the cell envelopes (Mitchell \& Moyle, $1951 b, c$ ). We therefore found it difficult to accept the view that the essential component of the so-called Gram complex is magnesium ribonucleate (Henry \& Stacey, 1943, 1946) and suggested that the new phosphoric ester might be part of the acidic cortical component which Gutstein (1925) considered to be responsible for the Gram staining reaction (Mitchell \& Moyle, 1950). In response to our observations, Jones, Muggleton \& Stacey (1950) reported that ribonucleic acids from different sources could substitute for one another in the 'Gram complex', and argued that '... one of the essential differences between $\mathrm{Cl}$. welchii and the various Gram-negative organisms studied is the presence in the Gram-positive organism of a particular type of protein, which when linked to magnesium ribonucleate is able to retain the Gram stain'. But they gave no further information about the protein or about the mechanism of retention of the stain. Previously, however, Webb (1949) had demonstrated the important fact that the magnesium contents of Grampositive and Gram-negative organisms differ significantly; the mean values for five Gram-positive and five Gram-negative bacteria grown on the same peptone medium were, respectively, c. $250 \mu$ mole $\mathrm{Mg}^{++}$and c. $60 \mu$ mole $\mathrm{Mg}^{++} / \mathrm{g}$. cell dry weight.

The data presented in the present paper have been collected from work carried out in 1950 and 1951 on the XSP content, the RNA and DNA content, and the lipid phosphorus and acid-soluble inorganic and organic phosphorus contents of some ten Gram-positive and ten Gram-negative organisms, grown in the same media and harvested at the same phase of growth.

\section{METHODS}

Growth and preparation of organisms. The bacteria were grown in a casein digest medium containing $1 \%(\mathrm{w} / \mathrm{v})$ glucose and $0.1 \%$ Marmite, except Acetobacter pasteurianum (NCIB 8088) which was grown in unhopped beer 
wort diluted with 4 vol. distilled water. The cultures of the aerobic organisms were aerated in rotated flasks (Mitchell, 1949) at $25^{\circ}$. The anaerobic organisms were grown in unstirred cultures in anaerobic jars at $25^{\circ}$. With one exception, the cells from measured volumes of the cultures were harvested by centrifuging during the phase of decelerated growth, washed twice with distilled water, freeze-dried and weighed. Cultures of Neisseria catarrhalis (NCTC 3622) were harvested at three different ages at which (i) practically all, (ii) about half, and (iii) practically none of the cells stained Gram-positive. The baker's yeast was the pressed Ark Yeast of Distillers Co. Ltd.; it was freeze-dried before use.

Fractionation of freeze-dried organisms. The methods of Mitchell \& Moyle (1951 c) and Mitchell (1953) were used to estimate the lipid weight $(\mathrm{L})$, and the $\mathbf{P}$ content of the following fractions: the acid soluble inorganic phosphate (AI) and organic phosphate (AO); the lipid (LP); the RNA and XSP; and the DNA.

Gram staining. Heat-fixed films of the organisms were stained with $\mathbf{0 . 5} \%$ $(\mathrm{w} / \mathrm{v})$ aqueous crystal violet for $30 \mathrm{sec}$, mordanted with $1 \%(\mathrm{w} / \mathrm{v})$ iodine in $\mathbf{2} \%$ aqueous $\mathrm{KI}$ for $\mathbf{3 0}$ sec. and differentiated with $\mathbf{9 5} \%$ ethanol. After washing with water, the films were counterstained with $0 \cdot 1 \%(\mathrm{w} / \mathrm{v})$ neutral red in 20 p.p.m. aqueous acetic acid for $2 \mathrm{~min}$.

\section{RESULTS}

Table 1 describes the characteristics of the organisms : the cell-suspension density at harvesting in $\mathrm{mg}$. cell dry weight/100 ml. culture (written $\mathrm{mg} . \mathrm{H} / \mathbf{1 0 0} \mathrm{ml}$.); the lipid content in $\mathrm{mg}$./g. cell dry weight (written $\mathrm{mg}$. L/g.); the $\mathbf{P}$ content of the fractions in $\mu$ mole $\mathrm{P} / \mathrm{g}$. cell dry weight; and the Gram reaction (written + or - ). In some of the organisms, not all the fractions were estimated. The RNA fractions of all the organisms for which the RNA content is given were examined for inorganic phosphate corresponding to the phosphoprotein of Schmidt \& Thannhauser (1945). In no case was there as much as $1 \mu$ mole inorganic $\mathbf{P} / \mathrm{g}$. cell dry weight.

The results for the Gram-positive and Gram-negative groups of bacteria (the Gram-variable Neisseria and the yeast being omitted) have been analysed separately and set out as histograms in Figs. 1-4. In each histogram, the arrow shows the arithmetic mean value for the fraction under consideration; the width of each block is equal to the standard deviation of the individual values from the mean; and the height of each block represents the number of organisms in which the value of the fraction falls within the range indicated by the width of the block.

There is no significant difference between the contents of DNA and RNA in the Gram-positive and Gram-negative groups of organisms (Fig. 1). There are, however, significant differences in the other phosphate fractions. The Grampositive organisms contain more of the acid-soluble fractions AI and AO than the Gram-negative organisms (Fig. 2). The lipid weight (Fig. 4) does not differ significantly in the two groups, but the mean phosphorus content of the lipid (Figs. 3, 4) is $1.65 \%(w / w)$ in the Gram-positive group and $3.3 \%$ in the Gram- 
Table 1. The dry-weight concentration at harvesting, the lipid weight, the $\mathbf{P}$ content of the fractions and the Gram reaction of several micro-organisms

\begin{tabular}{|c|c|c|c|c|c|c|c|c|c|c|}
\hline \multirow[b]{2}{*}{ Organism } & \multirow{2}{*}{$\begin{array}{l}\text { mg.H/ } \\
100 \mathrm{ml} .\end{array}$} & \multirow{2}{*}{$\begin{array}{l}\text { mg.L/ } \\
\text { g. }\end{array}$} & \multicolumn{7}{|c|}{$\mu$ mole $\mathrm{P} / \mathrm{g}$. cell dry-weight } & \multirow{2}{*}{$\begin{array}{l}\text { Gram } \\
\text { reaction }\end{array}$} \\
\hline & & & LP & AI & AO & RNA & DNA & $\mathrm{XSP}$ & Tot. & \\
\hline $\begin{array}{l}\text { Acetobacter pasteurianum } \\
\quad \text { (NCIB 8088) }\end{array}$ & 30 & . & 48 & 15 & 57 & 472 & 53 & -9 & 636 & - \\
\hline Aerobacter aerogenes $(\mathrm{A})$ & 210 & 49 & 62 & 50 & 46 & 407 & . & 4 & 594 & - \\
\hline $\begin{array}{l}\text { Alcaligenes faecalis } \\
\quad \text { (NCTC 415) }\end{array}$ & 150 & 85 & 87 & 27 & 37 & 388 & 97 & 13 & 649 & - \\
\hline Azotobacter agile (NCIB 8004) & 20 & 121 & 148 & 25 & 72 & . & . & . & 701 & - \\
\hline Bacillus brevis (NCTC 7577) & 70 & 48 & 45 & 31 & 29 & 410 & 73 & -10 & 578 & - \\
\hline Escherichia coli $(\mathbf{H})$ & 100 & 68 & 63 & 26 & 42 & 345 & 180 & 8 & 664 & - \\
\hline Esch. coli (MS) & 70 & . & & 10 & 63 & 323 & . & 2 & 467 & - \\
\hline Proteus vulgaris (882) & 120 & 70 & 73 & 48 & 22 & 365 & 94. & $\mathbf{3}$ & 625 & - \\
\hline $\begin{array}{l}\text { Pseudomonas aeruginosa } \\
\text { (NCTC 8203) }\end{array}$ & 80 & 83 & 103 & 41 & 50 & $\cdot$ & $\cdot$ & . & · & - \\
\hline $\begin{array}{l}\text { Serratia marcescens } \\
\quad(\text { NCTC } 1377)\end{array}$ & 100 & 60 & 68 & 43 & 53 & 407 & $\cdot$ & 16 & 608 & - \\
\hline $\begin{array}{l}\text { Neisseria catarrhalis (NCTC } \\
\text { 3622) }\end{array}$ & 70 & 81 & 82 & 26 & 163 & 560 & 123 & -4 & 950 & - \\
\hline N. catarrhalis (NCTC 3622) & 13 & . & . & . & . & 470 & 132 & 92 & . & \pm \\
\hline N. catarrhalis (NCTC 3622) & 3 & . & & . & . & 536 & . & 154 & . & + \\
\hline Baker's yeast (Distillers Co. Ltd.) & 1.) . & 27 & $9 \cdot 4$ & 47 & 45 & 169 & 22 & 60 & 352 & + \\
\hline $\begin{array}{l}\text { Bacillus subtilis (isolated from } \\
\text { hay) }\end{array}$ & 100 & 48 & 16 & 70 & 238 & 291 & 71 & 471 & 1157 & + \\
\hline Clostridium sporogenes $(\mathbf{J})$ & 40 & 51 & 42 & 71 & 56 & 426 & 75 & 103 & 773 & + \\
\hline Cl. welchii (SR 12) & 30 & 55 & 45 & 37 & $\mathbf{3 0}$ & 491 & 130 & 226 & 959 & + \\
\hline $\begin{array}{l}\text { Corynebacterium xerosis (NCTC } \\
\text { 7247) }\end{array}$ & 120 & 65 & 36 & 92 & 129 & 270 & 65 & 385 & 977 & + \\
\hline Lactobacillus casei (ATCC 7469) & 25 & 63 & 28 & 63 & 129 & 188 & 84 & 168 & 660 & + \\
\hline Mycobacterium phlei (Söhn) & 90 & 107 & 37 & 49 & 106 & 326 & 89 & 126 & 733 & + \\
\hline Staphylococcus aureus (Duncan) & ) 300 & 60 & 38 & 166 & 110 & 197 & 73 & 250 & $\mathbf{8 3 4}$ & + \\
\hline Streptococcus faecalis (Dunn) & 90 & 59 & 26 & 146 & 266 & 459 & 168 & 232 & 1297 & + \\
\hline Strep. faecalis (ST) & 100 & 52 & 29 & 200 & 129 & 417 & 111 & 161 & 1047 & + \\
\hline
\end{tabular}

negative group of organisms. The greatest difference is shown by the XSP fraction, which is present in all the Gram-positive organisms studied, but not present in significant amounts in the Gram-negative ones (Fig. 3). The total phosphate (Fig. 4) reflects the excess of AO, AI and XSP, and the relatively smaller deficit of LP in the Gram-positive group.

\section{DISCUSSION}

The present observations largely confirm our earlier results (Mitchell \& Moyle 1950). Differences occur, however, because we previously used a less efficient method of lipid extraction with the result that part of the lipid phosphorus passed into the XSP fraction. We also employed a low mean mononucleotide extinction coefficient for nucleic acid (8200), taken from the literature, in place of the present experimentally determined value of 10,000 (Mitchell \& Moyle, $1951 b$ ) in agreement with that of Wyatt (1950). The errors introduced by the above two factors were partially compensatory in most cases, but we were previously unable to demonstrate XSP in the clostridia. The present results 
show, however, that the clostridia, like all the other Gram-positive organisms studied, contain XSP.

There is a reciprocal relationship between XSP and LP content which suggests that the presence of the XSP-containing component may be related to the deficit of lipid phosphorus. For, whereas the mean $\mathbf{P}$ content of the

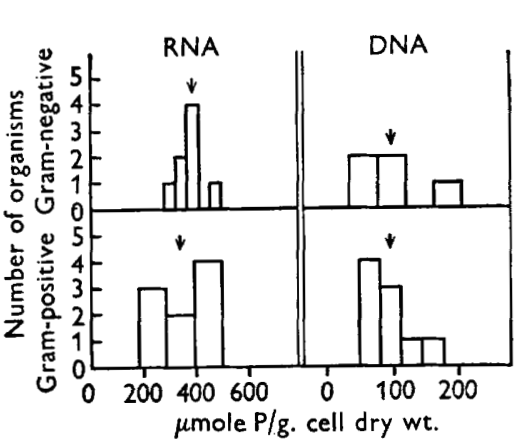

Fig. 1. The distribution of organisms with respect to RNA and DNA content.

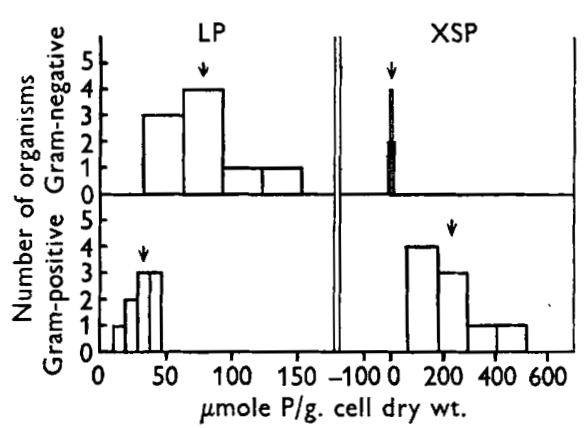

Fig. 3. The distribution of organisms with respect to LP and XSP content.

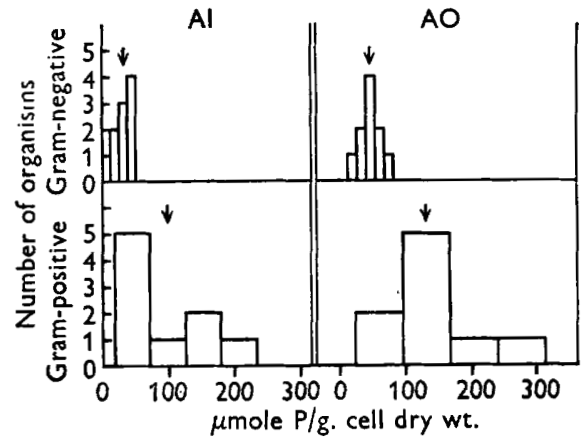

Fig. 2. The distribution of organisms with respect to $A I$ and $A O$ content.

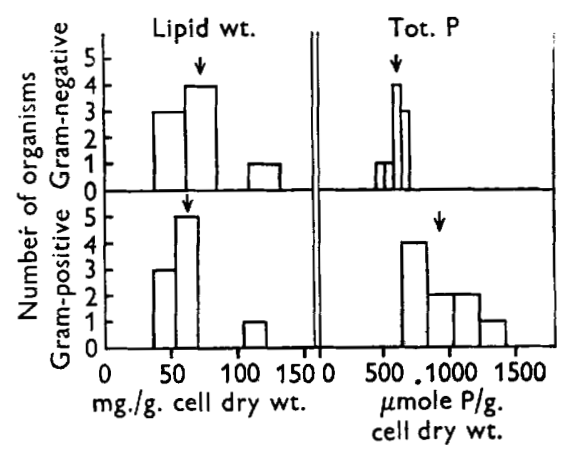

Fig. 4. The distribution of organisms with respect to lipid wt. and Tot. $P$ content.

lipid of the Gram-negative organisms $(3.3 \% \mathrm{P})$ approximates to that of a phospholipid like lecithin $(4.0 \% \mathrm{P})$, the mean $\mathrm{P}$ content of the lipid of the Gram-positive organisms is only about half as great $(1 \cdot 65 \% \mathrm{P})$.

It should be borne in mind that the amount of lipid phosphorus obtained is dependent to a considerable extent on the method of extraction. The method which we have employed (repeated heating of the dry material with methanol and extraction with dry ether) was found by Reichert (1944) to yield an amount of lipid approximating closely to that obtained after mild acid hydrolysis. The method nevertheless remains an empirical one, the word lipid, in the present paper, being effectively defined by our method of extraction. The treatment with boiling methanol may be sufficient to break certain labile covalent bonds, releasing ether-soluble material which was originally chemically linked to insoluble components. On the other hand, it may be 
insufficient to release certain ether-soluble material which is attached to the residue only by van der Waals forces.

We included Bacillus brevis in the Gram-negative group of organisms because, in spite of its staining character, it possesses all the normal physiological characteristics of the Gram-positive aerobic spore-forming rods. The fact that $\boldsymbol{B}$. brevis lacks XSP adds considerable weight to the correlation between XSP content and Gram staining, as does also the fact that 'young' Grampositive cultures of $N$. catarrhalis contain XSP, whereas 'old' Gram-negative cultures do not. In Staphylococcus aureus, the XSP-containing component is a polyglycerophospho-compound, part of which is bound to the protein of the cell wall and part to the underlying lipo-protein membrane (Mitchell \& Moyle, $1951 c$ ). We therefore suggest that a lipid-polyglycerophosphate-protein component may be a common structural feature of the cell envelopes of all Grampositive bacteria, and that it is this feature which shows up as the XSP and low LP in the analyses of the whole cells.

The work of Newton (1953) and our own recent unpublished observations show that Gram-negative organisms lose significant amounts of the acidsoluble components when washed in distilled water, whereas Gram-positive organisms generally do not. Since all the organisms studied in the present work were washed with distilled water, the differences observed in the contents of the acid-soluble components may be due, at least in part, to a greater osmotic fragility of the envelopes of the Gram-negative group.

The values for the RNA and DNA contents of the organisms confirm our previous observations that the Gram-positive and Gram-negative groups of organisms do not differ significantly with respect to content of the nucleic acids (Mitchell \& Moyle, 1950). The mean total nucleic acid phosphorus (RNA + DNA) content of all the organisms studied is $c$. $470 \mu \mathrm{mole} / \mathrm{g}$., compared with an arginine content of c. $450 \mu \mathrm{mole} / \mathrm{g}$. in Gram-positive organisms and c. $900 \mu \mathrm{mole} / \mathrm{g}$. in Gram-negative ones. Thus, even without taking into consideration the XSP-containing component, the net negative charge attached to the cells (after fixation of the cells and loss of the small molecular weight solutes) must be much greater in Gram-positive than in Gram-negative organisms. This may explain the difference in the so-called isoelectric points of the Gram-positive and Gram-negative groups of bacteria (c. $\mathrm{pH} 3$ and 5 respectively), measured by the $\mathrm{pH}$ at which the same amounts of an acidic and a basic dye are retained by the cells after staining in water and washing rapidly with ethanol (Stearn \& Stearn, 1924). It has often been stated on the basis of the results of Stearn \& Stearn that Gram-positive bacteria are more acidic than Gram-negative ones. We should note, however, that a large part of the difference in 'isoelectric point' should be attributed to the fact that Gram-positive bacteria are less basic than Gram-negative bacteria. On the other hand, Gram-positive bacteria may carry a greater number of negatively charged groups than Gram-negative bacteria because of the presence of the XSP-containing component. It is most unlikely that more than one hydroxyl group is free per phosphorus atom of the XSP-containing component, and hence the additional negative charge contributed by the XSP of the average 
Gram-positive bacterium would not exceed c. $240 \mu$ equivalents/g.-somewhat more than half as great as the contribution due to the deficit of arginine $(450 \mu \mathrm{mole} / \mathrm{g}$.). The lower 'isoelectric point' of Gram-positive bacteria may therefore be attributed mainly to the presence of less basic groups.

When the movable ions are considered, the cells must, of course, be electrically neutral. It is therefore interesting that the deficit of the monovalent arginine residues in Gram-positive organisms (c. $450 \mu \mathrm{mole} / \mathrm{g}$.) is largely compensated by the excess of the divalent magnesium ion $(c .190 \mu \mathrm{mole} / \mathrm{g}$. $)$. This suggests the following ion exchange hypothesis which has not, to our knowledge, been considered before as a factor in the Gram reaction. The uptake of crystal violet by the negatively charged components of Gram-positive cells may be accompanied by the displacement and escape of the magnesium counter ions, whereas in Gram-negative organisms the counter ions (being mainly the arginine residues of the cell proteins) may be displaced by the crystal violet but cannot escape. On washing with neutral ethanol, the stain is retained by Gram-positive cells because no counter ions are available, whereas it is not retained by Gram-negative cells because the arginine counter ions can move back to their original positions. We consider this hypothesis to merit consideration as an explanation for the ionic part of the mechanism of Gram staining which is probably predominant when the mordant is omitted. It may also explain the Gram staining reaction (including the use of a mordant) of extracellular components such as the magnesium protein nucleates of micro-organisms and artificial protein nucleates (Henry, Stacey \& Teece, 1945) in which there is an excess of negatively charged groups associated with magnesium or other diffusible counter ions. The use of a mordant such as iodine, picric acid or mercuric iodide in the usual Gram method gives an incomparably sharper differentiation than can be obtained without a mordant (see, for example, Bartholomew \& Mittwer, 1952); and it is probable that an additional mechanism to that of ion exchange must be responsible for the great increase in differentiation which is achieved. In view of the large decrease in intensity or complete loss of normal Gram staining which occurs when the cell envelopes are ruptured and the escaped cell contents are retained on the slide by fixation, it has often been considered possible that the cell envelopes themselves play a part in preventing the outward diffusion of the stain. This possibility deserves further study in view of the evidence for the difference of composition of the envelopes of Gram-positive and Gramnegative bacteria.

We are indebted to many of our colleagues in the Department of Biochemistry, Cambridge, for advice and criticism, in particular to Dr G. Weber and Dr D. H. Northcote. One of us (J.M.M.) wishes to acknowledge the receipt of a grant from the Medical Research Council in support of this work.

\section{REFERENCES}

Bartholomew, J. W. \& Mrttwer, T. (1952). The Gram stain. Bact. Rev. 16, 1. Borvin, A. (1948). Les acides nucléiques dans la constitution cytologique et dans la vie bactérienne. C.R. Soc. Biol., Paris, 142, 1258. 
Camien, M. N., Salle, A. J. \& Dunn, M. S. (1945). Investigations of amino-acids, peptides and proteins. XXII. Percentage of some amino-acids in lactobacilli. Arch. Biochem. 8, 57.

Freeland, J. C. \& Gale, E. F. (1947). The amino-acid composition of certain bacteria and yeasts. Biochem. J. 41, 135 .

Gram, C. (1884). Über die isolierte Färbung der Schizomyceten in Schnitt- und Trockenpräparaten. Fortschr. Med. 2, 185.

Gutstein, M. (1925). Das Ektoplasma der Bakterien. III. und IV. Mitteilung: Morphologie und Aufbau des Ektoplasmas der grampositiven Bakterien. Z Zbl. Bakt. (1. Abt.), 95, 1.

Henry, H. \& Stacey, M. (1943). Histochemistry of the Gram-staining reaction for micro-organisms. Nature, Lond. 151, 671.

Henry, H. \& Stacey, M. (1946). Histochemistry of the Gram-staining reaction for micro-organisms. Proc. Roy. Soc. B, 133, 391.

Henry, H., Stacey, M. \& Teece, E. G. (1945). Nature of the Gram-positive complex in micro-organisms. Nature, Lond. 156, 720.

Jones, A. S., Muggleton, P. W. \& Stacey, M. (1950). The Gram complex in Clostridium welchii. Nature, Lond. 166, 650.

Mitcheld, P. (1949). A new technique for stirred aerated culture. Nature, Lond. $164,846$.

Mitchell, P. (1953). A micro lipid extractor. Nature, Lond. 172, 124.

Mitchell, P. \& Moyle, J. (1950). Occurrence of a phosphoric ester in certain bacteria: its relation to Gram staining and penicillin sensitivity. Nature, Lond. 166, 218.

Mitchell, P. \& Moyle, J. (1951 a). Relationships between cell growth, surface properties and nucleic acid production in normal and penicillin-treated Micrococcus pyogenes. J. gen. Microbiol. 5, 421.

Mitchell, P. \& Moyle, J. (1951 b). Isolation of hydrolytic products of a glycerophospho-compound from Micrococcus pyogenes. J. gen. Microbiol. 5, 966.

Mitcheld, P. \& Moyle, J. (1951 $c$ ). The glycerophospho-protein complex envelope of Micrococcus pyogenes. J. gen. Microbiol. 5, 981.

Newton, B. A. (1953). The release of soluble constituents from washed cells of Pseudomonas aeruginosa by the action of polymyxin. J. gen. Microbiol. 9, 54.

Reichert, R. (1944). Quantitative Bestimmung des Gesamtlipoidgehaltes von Naturstoffen. Helv, chim. Acta, 27, 961.

SAlton, M. R. J. (1953). Studies of the bacterial cell wall. IV. The composition of the cell walls of some Gram-positive and Gram-negative bacteria. Biochim. Biophys. Acta, 10, 512.

Schmidt, G. \& Thannhauser, S. J. (1945). A method for the determination of desoxyribonucleic acid, ribonucleic acid and phosphoproteins in animal tissues. J. biol. Chem. 161, 83.

Stacey, M. (1947). Bacterial nucleic acids and nucleoproteins. Symp. Soc. exp. Biol. $1,86$.

Stearn, E. W. \& Stearn, A. E. (1924). The chemical mechanism of bacterial behaviour. 1. Behaviour towards dyes; factors controlling the Gram reaction; 2. A new theory of the Gram reaction. J. Bact. 9, 463, 479 .

Stokes, J. L. \& GunNess, M. (1946). The amino-acid composition of micro-organisms. J. Bact. 52, 195.

WeBb, M. (1949). The influence of magnesium on cell division. II. The effect of magnesium on the growth and cell division of various bacterial species in complex media. J. gen. Microbiol. 3, 410.

Wyatт, G. R. (1950). Insect viruses and nucleic acids. Ph.D. Thesis, Cambridge. 